\title{
Peluang dan Tantangan Penerapan Otomasi Perpustakaan di Indonesia
}

\author{
Rhoni Rodin \\ Perpustakaan STAIN Curup- Rejang Lebong \\ Jl. Dr. Ak. Gani No.1, Rejang Lebong Bengkulu, 39119 \\ Email: rhoni.rodin@gmail.com
}

\begin{abstract}
Abstrak - Tulisan ini mengkaji mengenai bagaimana peluang dan dan tantangan dalam menerapkan teknologi dan informasi di Perpustakaan. Sebab mau tak mau perpustakaan harus menyikapi kemajuan zaman seperti sekarang ini. Oleh karena itu, perpustakaan haruslah mampu menjalankan tugas dan fungsinya dengan baik. Untuk itu perlu didukung dengan pemanfaatan aplikasi teknologi informasi terkini. Hal ini perlu mengingat perkembangan zaman dan tingkat kebutuhan masyarakat. Dalam penerapan sistem otomasi ini memang banyak mengalami resiko diantaranya kekurangan sumber daya manusia yang handal di bidang teknologi informasi, perubahan pola organisasi, dan dampak pada staf yang pada akhirnya kurang menerima sistem baru yang akan/ telah diterapkan.
\end{abstract}

Kata kunci: Otomasi, perpustakaan, teknologi informasi

Abstract - This paper examined the opportunities and challenges in applying information technology in Library. It is the library inevitably had to respond the progress of the times as it is today. Therefore, the library must be able to perform their duties and functions well. For that, library needs to be supported by the use of the latest information technology applications. It is necessary to remember the times and needs of the community. In the application of this automated system is much at risk include lack qualified human resources in the field of information technology, changing patterns of organization, and the impact on staff and ultimately less accept the new system that will be / have been applied.

Keywords: Automation, library, information technology

\section{PENDAHULUAN}

Gejala menarik di akhir abad XX dan memasuki abad XXI adalah semakin menipisnya batas-batas antar bangsa, dan semakin melemahnya faktor jarak sebagai salah satu unsur dalam hubungan antar manusia. Semuanya ini tak bisa dilepaskan dari kemajuan teknologi informasi
(TI) yang sedemikian tinggi. Maka dalam konteks ini dapat timbul dua kelompok sosial yang besar, yaitu pertama, kelompok masyarakat yang memiliki dan memanfaatkan prasarana komunikasi canggih dan dengan begitu mempunyai akses ke pusat-pusat informasi; kedua, kelompok masyarakat yang tidak mampu memiliki prasarana komunikasi canggih dan dengan begitu tetap terpuruk dalam ketertinggalannya.

Kemajuan teknologi informasi yang terjadi di zaman sekarang ini merupakan suatu hal yang tak bisa dihindari, bahkan sebaliknya harus diterima dengan lapang dada. Penerimaan terhadap kemajuan TI ini bukanlah diterima tanpa adanya filterisasi, tetapi filterisasi ini harus dilakukan. Perkembangan yang sangat pesat dalam bidang ilmu pengetahuan dan teknologi (iptek), terutama teknologi informasi yang kita sasksikan dewasa ini telah berdampak pada perubahan sendi-sendi etika dan moralitas kehidupan berbangsa. Bahkan merambah di segala bidang kehidupan baik ekonomi, sosial, maupun struktural kehiidupan. Sehingga Richard E. Rubin (2004) menyatakan bahwa ada beberapa gambaran ekspresi dalam menghadapi pertumbuhan informasi ini, yaitu: pertama, information explosion artinya ledakan informasi; kedua, The fload of Information artinya banjir informasi; ketiga, Bombarded by information artinya pengeboman oleh informasi; dan keempat, Information overload artinya terlampau banyak informasi.

Perpustakaan pada dewasa ini telah berkembang sedemikian rupa. Perkembangan perpustakaan pada dasawarsa ini telah dipengaruhi 
oleh perkembangan teknologi informasi (TI). Perpustakaan sebagai salah satu wadah yang mengumpulkan, mengolah dan mendistribusikan informasi mau tak mau harus berhadapan dengan teknologi informasi. Tidak sedikit orang beranggapan bahwa jika sebuah perpustakaan tidak bersentuhan dengan TI ini maka perpustakaan itu dianggap kuno, ketinggalan zaman dan tidak berkembang.

Perpustakaan sebagai salah satu infrastruktur informasi bertugas menyediakan informasi yang dibutuhkan pemakainya. Dengan adanya pergeseran paradigma perpustakaan yang berorientasi kepada pemakai (user), maka segala fasilitas perpustakaan diperuntukkan bagi pemenuhan pemakai (user) perpustakaan, apapun tujuan pencarian informasi tersebut.

Perpustakaan merupakan salah satu dari lembaga pengelola informasi, terutama informasi terkait dengan ilmu pengetahuan. Ledakan informasi yang melibatkan seluruh infrastruktur informasi membuat pustakawan mempunyai "saingan". Persaingan ini dapat menjadikan pustakawan sebagai peluang atau tantangan, bagi pustakawan yang kreatif, memiliki dedikasi tinggi dan kemampuan untuk mengaplikasikan teknologi informasi akan menjadi ujung tombak dalam penyebaran informasi, sedang bagi pustakawan yang malas dan tidak kreatif akan semakin tertinggal oleh perkembangan infromasi yang ada. Tantangan kedepan bagi pustakawan semakin berat, karena dituntut selalu berupaya melaksanakan tugasnya di bidang informasi, terutama dalam rangka menjalankan fungsi pendidikan.

\section{OTOMASI PERPUSTAKAAN}

Istilah otomasi perpustakaan mulai populer di Indonesia sekitar 1990-an. Walaupun saat ini paradigma tersebut mulai bergeser kearah perpustakaan elektronik (e-library) atau perpustakaan digital, tetapi konsep ini masih tetap "nyaring" didengungkan oleh pemula paham teknologi informasi. Beberapa perpustakaan perguruan tinggi telah lebih dahulu memanfaatkan tenologi ini. Bahkan telah dimulai semenjak tahun 1990-an.

Selain dari kecukupan dana untuk membangun otomasi perpustakaan, perhatian pemerintah (dalam hal ini Departemen Pendidikan) terhadap pengembangan otomasi perpustakaan juga relatif lebih besar. "Keberuntungan" ini memang lebih banyak diterima oleh perpustakaan perguruan tinggi, terutama perguruan tinggi negeri. Tercatat beberapa kali perpustakaan perguruan tinggi negeri memperoleh bantuan software otomasi untuk meningkatkan layanan perpustakaan. Hampir sama halnya dengan perguruan tinggi, Perpustakaan Nasional juga beberapa kali menyediakan fasilitas software gratis kepada jaringan perpustakaannya. Bahkan setelah gagal beberapa kali, Perpustakaan Nasional tidak pernah patah arang untuk menyediakan software gratis untuk jaringan perpustakaannya. Namun seiring berjalannya waktu, pengelola perpustakaan mulai frustasi dalam memanfaatkan sistem otomasi perpustakaan yang telah mereka bangun.

Kegalauan ini muncul antara lain akibat dari kegagalan sistem informasi (software), terutama menyangkut purna jual. Dari sinilah muncul stigma bahwa software "gratis" cendrung bermasalah. Konsep gratis disini sebenarnya bukan absolut. Pemerintah dalam hal ini Departemen Pendidikan dan Perpustakaan Nasional membeli software dari suatu vendor, kemudian didistribusikan kepada perpustakaan di bawah jaringannya. Namun, bagaimana dengan perpustakaan lain, seperti perpustakaan sekolah, perpustakaan umum, dan beberapa perpustakaan perguruan tinggi yang tidak memiliki cukup biaya untuk membangun otomasi perpustakaan? Apakah dalam era teknologi informasi ini, mereka masih tetap bertahan dengan sistem tradisional? Saat ini telah terbuka kesempatan bagi perpustakaan yang memiliki keterbatasan dana dalam membangun otomasi perpustakaan, yaitu Open Source Software (OSS).

Gerakan OSS telah dimulai pada tahun 1980an. Kemudian pada tahun 1998 beridiri 
organisasi Open Source Initiative (OSI). OSI bertujuan untuk memperoleh dukungan untuk OSS, artinya software tersebut juga menyediakan kode sumber seperti program (binary) yang sudah dapat dijalankan. OSI tidak menyediakan lisensi khusus, tapi mendukung berbagai macam tipe lisensi open source yang ada. Tujuan OSI adalah untuk merangkul perusahaan berbasis open source, perusahaan tersebut dapat menentukan sendiri bentuk lisensi open source yang mereka inginkan dan lisensi tersebut disahkan oleh OSI.

Jika seorang pengembang merasa tidak puas dengan para pengembang lain dalam membuat suatu proyek, maka ia dapat berpisah dan mengeluarkan proyek baru. Oleh karenanya diperlukan seorang pemimpin yang mampu bekerja sama dengan rekan-rekannya yang lain untuk membuat suatu arahan yang jelas tentang proyek. Namun penunjukan seorang pemimpin terkadang juga mengandung resiko. Proyekproyek open source biasanya dimulai oleh satu atau beberapa orang, sehingga ketergantungan menjadi sangat tinggi. Dengan berlalunya waktu, para pemimpin tersebut mungkin menjadi bosan, burn-out, dipekerjakan oleh organisasi lain. Akibatnya proyek-proyek yang mereka tangani dapat menjadi tertunda atau bahkan mungkin hilang. Sebagai contoh dua orang pembuat aplikasi GIMP, aplikasi open source untuk image editing seperti Adobe Photoshop, setelah mereka lulus dari Universitas California di Berkeley dan bekerja di organisasi lain, maka aplikasi GIMP yang mereka tulis sewaktu masih menjadi mahasiswa tertunda selama dua tahun pada saat versi 0.9 , sebelum akhirnya diteruskan oleh para pengembang baru lain.

Lebih lanjut Heryanto mengatakan bahwa umumnya software-software yang dikembangkan disebabkan karena menarik minat pengembang baik secara langsung maupun tidak langsung. Dengan adanya kecendrungan model open source yang dimulai oleh seorang individu maka pengembangannya akan lebih bersifat developer oriented, yang berarti software yang lebih kompleks, namun belum tentu lebih bermanfaat.
Pengembang akan membuat software-software yang terlihat menyenangkan, seperti membuat themes untuk GNOME, KDE maupun editor, dibandingkan dengan membuat aplikasi-aplikasi yang dianggap membosankan seperti Office Suites. Tanpa adanya insentif lain maka akan banyak proyek mati karena pengembang awal telah kehilangan minat dan tidak ada yang meneruskan.

\section{PELUANG DAN TANTANGAN PENERAPAN OTOMASI PERPUSTAKAAN DI INDONESIA}

Ada satu hal yang penting namun sering dilupakan ketika membahas tentang perpustakaan adalah kemampuan pustakawan untuk mengetahui apa sebenarnya yang diharapkan dari implementasi komputer dalam mendukung pelaksanaan tugas perpustakaan, dokumentasi dan jasa informasi. Komputerisasi ini bukanlah suatu mode, tetapi merupakan kebutuhan yang mendesak karena sesuai dengan zaman atau eranya yaitu era teknologi informasi.

Dibanding dengan sistem manual, sistem otomasi ini mempunyai resiko yang lebih besar yang tidak jarang menuju kepada kegagalan. Menurut Richard W Boss sebagaimana dikutip Blasius Sudarsono (2006) dijelaskan bahwa ada beberapa resiko yang sering muncul dalam usaha otomasi antara lain:

- Kekurangan sumber daya. Ketergantungan akan sistem menjadi mutlak. Sering terjadi ketika pembaharuan sistem yang dipakai ternyata terlalu cepat bagi perpustakaan, sehingga sukar baginya untuk mengejar kemutakhiran sistem dan memerlukan tambahan sumber daya yang memadai.

- Perubahan pola organisasi. Dengan berubahnya alur kerja berdasarkan konsepsi otomasi, dituntut perubahan pola atau struktur organisasi.

- Dampak pada staf. Banyak disebut tentang penolakan staf terhadap sistem otomasi. Hal ini tidak berarti bahwa mereka tidak menyetujui otomasi, namun lebih bersifat 
kesukaran dalam mengubah pola pikir dari sistem manual menjadi sistem otomasi. Hal ini tentu akan mempengaruhi pola tindak menjadi tidak efisien.

Selain dari pada itu Prof. Sulistyo Basuki (1994) menyatakan bahwa dilema yang dihadapi pustakawan Indonesia adalah apakah sudah waktunya automasi perpustakaan? Manakah yang lebih penting, automasi perpustakaan ataukah pengembangan koleksi? Apakah komputer merupakan kemewahan ataukah merupakan sebuah kebutuhan? Dilema ini menimbulkan pertentangan antara yang pro melawan yang kontra. Di samping dilema ini, masih ada kendala automasi perpustakaan yang berasal dari intern maupun dari luar. Tapi terlepas dari dilema yang ada ini, penerapan otomasi perpustakaan ini sudah merupakan tuntutan perkembangan zaman.

Perpustakaan haruslah mampu menjalankan tugas dan fungsinya dengan baik. Untuk itu perlu didukung dengan pemanfaatan aplikasi teknologi informasi terkini. Hal ini perlu mengingat perkembangan zaman dan tingkat kebutuhan masyarakat. Pemustaka, khususnya anak muda tentu akan lebih tertarik jika perpustakaan dilengkapi dengan fasilitas modern seperti internet, koleksi digital, dan hot spot area. Ini membuat perpustakaan lebih gaul di mata mereka, sekaligus menghilangkan paradigma lama bahwa perpustakaan itu kuno dan membosankan. Oleh karena itu, mau tak mau penerapan otomasi ini merupakan tuntutan zaman yang harus segera diterapkan oleh para pengambil kebijakan (policy) demi terciptanya perpustakaan yang ideal sesuai dengan perkembangan zaman.

Banyak cara dilakukan oleh perpustakaan untuk membangun otomasi perpustakaan. Mulai dari membeli, merancang sendiri, mengadopsi perangkat lunak khusus perpustakaan, sampai dengan memanfaatkan Open Source SortwareLibrary Managemen System (OSS-LMS). Beberapa perpustakaan ada yang berhasil melakukan otomasi perpustakaan, namun banyak juga yang berguguran.
Arwendria (2009) menuturkan bahwa banyak faktor yang menyebabkan gagalnya penerapan otomasi perpustakaan. Secara umum ada tiga faktor penyebab kegagalan implementasi otomasi perpustakaan. Pertama, perangkat lunak yang digunakan tidak bisa dikembangkan sesuai dengan kebutuhan perpustakaan. Pengelola perpustakaan sering ikut-ikutan menggunakan perangkat lunak perpustakaan yang digunakan oleh perpustakaan lain tanpa memperhitungkan perbedaan karakteristik dengan perpustakaan tersebut. Bila perangkat lunak tersebut dirancang sendiri, maka perpustakaan harus memahami manajemen perpustakaan dengan baik, sehingga pengembang perangkat lunak mampu memahami kebutuhan perpustakaan dengan baik.

Kalau setiap perpustakaan membeli atau mengembangkan sendiri perangkat lunak untuk otomasi perpustakaannya, maka dapat dihitung berapa jumlah uang yang dihambur-hamburkan untuk membuat perangkat lunak sejenis. Sebenarnya, pihak-pihak terkait sudah mencoba membuat perangkat lunak khusus perpustakaan untuk dimanfaatkan bersama. Namun, pengembangannya sering terhenti di tengah jalan, sehingga perpustakaan yang menggunakan software tersebut juga berhenti mengaplikasikan perangkat lunak tersebut.

Saat ini sedang marak-maraknya penggunaan OSS, termasuk pada perpustakaan. Tercatat beberapa perangkat lunak gratis yang dapat diunduh dengan mudah melalui internet, seperti Senayan, OtomigenX, OpenBiblio, Koha, dll. Dari sekian banyak OSS yang beredar, Senayan merupakan perangkat lunak yang banyak mendapat perhatian dari pemerhati perpustakaan. Perangkat lunak ini dikembangkan oleh Departemen Pendidikan Nasional yang secara berkala diupdate oleh pengembang berdasarkan masukan dari para pengguna Senayan di seluruh Indonesia. Perangkat lunak ini dikembangkan berbasis web, sehingga peralihan dari otomasi ke perpustakaan digital dapat dilakukan dengan serentak. 
Karena prinsip dasar OSS adalah dikembangkan untuk umum, maka belum tentu perangkat lunak tersebut sesuai dengan kebutuhan perpustakaan. Agar sesuai dengan kebutuhan perpustakaan, sebaiknya beberapa perpustakaan sejenis berkolaborasi untuk mendasain ulang perangkat lunak tersebut sehingga sesuai dengan kebutuhan perpustakaan dengan biaya relatif lebih murah.

Kedua, terbatasnya pengetahuan staf terhadap dalam menggunakan perangkat lunak dan perangkat keras. Penguasaan pemanfaatan teknologi informasi dan komunikasi merupakan harga mutlak untuk dipahami oleh pustakawan. Teknologi adalah alat untuk mencapai tujuan. Apabila tujuannya adalah untuk menyediakan akses ke informasi agar dapat ditemukan secara efektif dan efisien, maka cara memanfaatkan teknologi tersebut juga harus diketahui oleh user (pemakai). Pengetahuan terhadap sumber-sumber informasi menjadi bagian dari pekerjaan rutin pustakawan, dan user (pemakai) harus mengetahui bagaimana memanfaatkan sumber-sumber informasi tersebut. Setiap pustakawan harus mampu memahami rencana strategis yang dikembangkan oleh perpustakaan. Selanjutnya, pustakawan harus mampu memahami perilaku pemakainya. Dengan kata lain, selain pustakawan mampu memanfaatkan teknologi informasi dan komuikasi tersebut, pustakawan juga harus mampu melatih pemakai untuk memanfaatkan jasa perpustakaan dengan media tersebut.

Urs (2002) dalam Aqili dan Moghaddam (2007) dengan rinci menggambarkan bidang, tugas dan syarat keahlian dan pengetahuan yang mutlak dimiliki oleh pustakawan di era teknologi informasi dan komunikasi. Menurutnya, pustakawan harus memiliki pengetahuan dalam bidang kajian pemakai informasi, sumber-sumber informasi, penambahan nilai informasi, teknologi informasi, dan manajemen. Kompetensi inilah yang mutlak dimiliki oleh pustakawan di era teknologi informasi.

Menyikapi padangan Urs di atas dapat disimpulkan bahwa perpustakaan memang harus dikelola oleh orang yang memiliki pengetahuan terhadap ilmu informasi dan perpustakaan, bukan oleh mereka yang "dipaksa atau terpaksa" bekerja di perpustakaan. Pustakawan menurut Undangundang Perpustakaan No. 43 Tahun 2007 seperti tertuang pada Pasal 1 adalah seseorang yang memiliki kompetensi yang diperoleh melalui pendidikan dan/atau pelatihan kepustakawanan serta mempunyai tugas dan tanggung jawab untuk melaksanakan pengelolaan dan pelayanan perpustakaan. Selanjutnya pada Pasal 29 ayat 3 menyebutkan:

"Pustakawan sebagaimana dimaksud pada ayat (1) harus memenuhi kualifikasi sesuai dengan standar nasional perpustakaan."

Secara nyata terlihat bahwa pengambil kebijakan sudah seharusnya mulai "mempekerjakan" mereka yang memiliki kualifikasi sebagaimana diamanatkan oleh undang-undang tersebut. Di sisi lain, amanat tersebut merupakan peluang dan sekaligus tantangan bagi lulusan jurusan atau program studi ilmu informasi dan perpustakaan. Sulistyo-Basuki (1994) mengatakan bahwa lebih dari tujuh ribu sekolah di Indonesia membutuhkan profesi pustakawan.

Ketiga, perangkat teknologi informasi membutuhkan perawatan, bahkan pada perangkat tertentu perlu diperbaharui karena tidak lagi didukung dengan suku cadang di pasaran. Seringkali perpustakaan lalai dalam memasukkan aspek perawatan peralatan teknologi informasi dan komunikasi pada perencanaan tahunannya. Secara umum, biaya yang harus dialokasikan untuk perawatan peralatan tersebut lebih kurang sebesar $10 \%$ dari investasi.

Kemudian menurut Abdul Rahman Saleh (2006) ada beberapa hal yang menjadi penyebab mengapa kita harus melakukan otomasi perpustakaan, yaitu:

1. Tuntutan terhadap penggunaan koleksi secara bersama (resource sharing)

Suatu perpustakaan tidak akan bisa memenuhi begitu banyaknya kebutuhan 
pemustaka (user) tanpa melakukan kerjasama dalam hal koleksi dengan perpustakaan lain.

2. Kebutuhan untuk mengefektifkan sumberdaya manusia

Dengan efisiensi tenaga seperti ini maka perpustakaan dapat memikirkan dan mengalokasikan tenaga untuk menyelenggarakan layanan-layanan lain yang dapat diberikan kepada pemakai.

3. Tuntutan terhadap efisiensi waktu

Artinya dengan adanya otomasi ini bisa mempercepat layanan atas informasi yang diinginkan oleh user.

4. Kebutuhan akan ketepatan layanan informasi Selain kecepatan dalam memperoleh informasi, pemakai juga membutuhkan ketepatan informasi yang didapatkannya dari perpustakaan. Pertanyaan-pertanyaan tentang informasi secara spesifik harus bisa dijawab secara spesifik pula. Dengan bantuan teknologi komputer pertanyaan-pertanyaan ini bisa dijawab dengan cepat dan tepat.

5. Keragaman informasi yang dikelola

Informasi yang ada di perpustakaan saat ini tidak hanya terbatas kepada buku dan jurnal ilmiah saja. Informasi-informasi lain seperti audio visual, multimedia, bahan mikro, media optik dan sebagainya saat ini juga dikoleksi oleh perpustakaan. Banyak koleksi perpustakaan yang harus di baca dengan menggunakan teknologi komputer. Selain itu untuk mengelola informasi yang sangat beragam tersebut diperlukan bantuan alat terutama teknologi komputer.

Berdasarkan dari penjelasan-penjelasan diatas dapat dipahami bahwa di satu sisi otomasi perpustakaan ini merupakan suatu keharusan atau tuntutan dan kebutuhan. Karena kemajuan teknologi informasi menuntut perpustakaan untuk membenahi diri sesuai dengan perkembangan zaman, artinya otomasi perpustakaan ini sudah saatnya diterapkan pada perpustakaanperpustakaan yang ada di Indonesia. Tapi di sisi lain ada beberapa daerah di Indonesia ini belum siap untuk menerapkan otomasi perpustakaan ini.
Ketidaksiapan itu disebabkan oleh sumber daya manusianya yang belum memadai, artinya SDMnya masih sangat minim dalam menunjang penerapan otomasi. Selain dari pada itu, kendala teknis yang belum menunjang penerapan otomasi ini, kendala teknis ini bisa berupa aliran listrik yang tidak stabil karena sering dipadamkan. Disamping itu yang tak kalah penting adalah kemampuan pemakai dalam memahami dan menerapkan teknologi informasi ini. Artinya percuma suatu perpustakaan memberikan penampilan yang eksklusif (dalam hal ini menggunakan otomasi) tetapi user-nya tidak tahu bagaimana cara menggunakannya.

\section{SIMPULAN}

Penggunaan teknologi informasi bukan dimaksudkan untuk menggantikan pekerjaan pustakawan, melainkan untuk mempercepat proses pekerjaan sehingga pustakawan dapat melakukan pekerjaan lain yang lebih berorientasi pada pemberian jasa informasi kepada perpustakaan. Informasi tersebut akan sangat bermakna bagi pemakai apabila informasi yang diberikan sesuai dengan kebutuhan mereka dan dapat mereka akses dari mana saja, kapan saja, dan melalui saluran apa saja.

Perpustakaan sebaiknya membiasakan diri telebih dahulu dengan otomasi perpustakaan sebelum menuju ke perpustakaan digital. Otomasi perpustakaan lebih pada percepatan in house activities, sedangkan perpustakaan digital pada nilai kolaborasinya. Ketika segala aspek perpustakaan telah siap, dan penggunaan teknologi informasi telah berkembang penggunaannya di lembaga induk, maka era digital di perpustakaan menjadi kepatutan.

Penerapan otomasi perpustakaan di Indonesia saat ini merupakan tuntutan zaman agar tidak terlalu jauh ketinggalan dari negara lain. Walaupun memang masih banyak kendala yang harus dihadapi, tetapi semuanya harus dilakukan secara bertahap sehingga nantinya bisa mencapai hasil yang sempurna (excellent). 


\section{DAFTAR PUSTAKA}

Aqili, Seyed Vahid dan Alireza Isfandyari Moghaddam. 2008. Bridging the Digital Devide: The Role of Librarians and Information Professionals in Third Millennium. The Electronic Library 20, 2: 226-237.

Arwendri. 2009. Strategi Membangun Otomasi Perpustakaan untuk Mendukung Kualitas Pendidikan di era Teknologi Informasi. Makalah yang disampaikan pada Seminar Nasional Kebijakan Pengembangan Pendidikan Menghadapi Era Globalisasi dalam rangka Dies Natalis Universitas Lancang Kuning XXVII pada hari Jum'at 05 Juni 2009

Basuki, Sulistyo. 1994. Periodesasi Perpustakaan Indonesia, Bandung: Remaja Rosdakarya.

Rubin, Richard E. 2004. Foundations of Library and Information Science $2^{\text {nd }}$ edition, New York: Neal-Schuman Publisher.

Blasius Sudarsono. 2006. Antologi Kepustakawanan Indonesia, Jakarta: Pengurus Pusat Ikatan Pustakawan Indonesia.

Republik Indonesia. 2007. Undang-undang Republik Indonesia No. 43 Tahun 2007 Tentang Perpustakaan.

Saleh, Abdul Rahman, 2006. Strategi Penerapan Teknologi Informasi (Digital Library) di Perpustakaan dan Pusat Informasi, Bogor: Buletin Perpustakaan dan Informasi. 